\title{
Photoprotective property and cytotoxicity of polar extracts of three species of Maytenus native to the Southwest of Bahia
}

\author{
Propriedade fotoprotetora e citotoxicidade de extratos polares de três espécies de Maytenus \\ nativas do sudoeste da Bahia
}

\author{
R. S. Pereira'; R. M. Aguiar'; G. S. Lemos'; S. A. Vieira Filho²; D. M. de \\ Oliveira $^{3 *}$ \\ ${ }^{1}$ Universidade Estadual do Sudoeste da Bahia, Departamento de Ciências Tecnológicas, 45.200-000, Jequié-BA, \\ Brazil. \\ ${ }^{2}$ Universidade Federal de Ouro Preto, Departamento de Farmácia, Campus Morro do Cruzeiro, 35400-000, Ouro \\ Preto-MG, Brazil. \\ ${ }^{3}$ Universidade Estadual do Sudoeste da Bahia, Programa de Pós-Graduação em Química, 45.200-000, Jequié-BA, \\ Brazil. \\ *djalmao23@gmail.com
}

(Recebido em 18 de dezembro de 2019; aceito em 07 de fevereiro de 2020)

\begin{abstract}
Maytenus acanthophylla, M. rigida and M. truncata (Celastraceae) are used in the traditional medicine of Chapada Diamantina and Southwest Bahia, Brazil. The infusion and decocto of its leaves are used in the treatment of inflammation and gastric disorders. In this context, it is important to identify chemical and biological properties that reinforce this traditional use. The objective of this study was to determine the total phenolic and flavonoid content by the Folin-Ciocalteau method, the photoprotective property by in vitro spectrophotometric method and the acute toxicity by the mortality index of Artemia salina, of polar extracts of these three Maytenus species. It was observed that the species have similar levels of total phenolic and flavonoid. The presence of compounds containing chromophore groups, which absorb radiation in the UV region between 290 and $320 \mathrm{~nm}$, gives the extracts promising sun protection factors. In the tests with $A$. salina, the median lethal concentration values were high $(\geq 1000.0 \mu \mathrm{g} / \mathrm{mL})$ indicating the low toxicity of these extracts. The results contribute to the knowledge of the polar extracts of the three Maytenus species of the Southwest of Bahia, to the validation of the therapeutic properties of these plants and opens perspectives of new studies of photoprotection.

Keywords: Maytenus spp., photoprotection,citotoxicity.
\end{abstract}

Maytenus acanthophylla, M. rigida e M. truncata (família Celastraceae) são utilizadas na medicina tradicional da Chapada Diamantina e do Sudoeste da Bahia, Brasil. A infusão e o decocto de suas folhas são utilizados no tratamento de inflamações e distúrbios gástricos. Nesse contexto, é importante identificar propriedades químicas e biológicas que reforcem este uso tradicional. O objetivo deste trabalho foi determinar o teor de fenólicos totais e de flavonoides pelo método Folin-Ciocalteau, a propriedade fotoprotetora por método espectrofotométrico in vitro e a toxicidade aguda através do índice de mortalidade de Artemia salina, de extratos polares dessas três espécies de Maytenus. Observou-se que as espécies possuem teores similares de fenólicos totais e de flavonoides. A presença de compostos contendo grupos cromóforos, que absorvem radiação na região do UV entre 290 a $320 \mathrm{~nm}$, confere aos extratos fatores de proteção solar promissores. Nos ensaios com A. salina, os valores de concentração letal mediana foram altos $(\geq 1000.0 \mu \mathrm{g} / \mathrm{mL})$ indicando a baixa toxicidade dos extratos. Os resultados contribuem para o conhecimento dos extratos polares das três espécies de Maytenus do Sudoeste da Bahia, para a validação das propriedades terapêuticas destas plantas e abre perspectivas de novos estudos de fotoproteção.

Palavras-chave: Maytenus spp., fotoprotetora, toxicidade.

\section{INTRODUCTION}

Many medicinal plant species are still routinely used in folk medicine around the world, mainly due to the easy accessibility for low-income people $[1,2]$. It is estimated that $40 \%$ of the medicines currently available for clinical use are synthetic derivatives of natural products, with $25 \%$ originating from medicinal plants [2]. Due to this fact, in the last decades the World Health Organization (WHO) and the Pan-American Health Organization (PAHO) recognized and began 
to stimulate the use of herbal medicines for several diseases that affect the population, contributing to the health of users of public health systems [3, 4]. In addition, in several countries there has been an increase in government interest in associating the popular knowledge related to the use of medicinal plants and technological advancement with a sustainable development aiming at an effective health care system, in a comprehensive, humanized way and associated with pharmaceutical technology [5].

In this context, Brazil contains approximately $13 \%$ of the global biota and, as a result, the search for substances obtained from Brazilian plants that have pharmacological potential stands out in science [6]. Thus, in terms of research in the area of Pharmacognosy, the Brazilian biodiversity represents an important source of bioactive substances, highlighting species of the Celastraceae family.

The Celastraceae family consists of 106 genera and 1300 species distributed mainly in tropical and subtropical regions [7]. In Brazil, this family is represented by the genus Maytenus Juss, Plenckia Lund, Franhofera Mart. and Salacia Mart. [8], of which many have already been accurately studied [9].

Maytenus is one of the main genera of the Celastraceae family. Species of this genus are found in several continents, mainly those of tropical climate and, many of them are traditionally used by people of different cultures [10,11]. For some Maytenus species, properties such as anti-rheumatic, antibacterial, antitumoral, healing, anti-inflammatory, insecticidal and immunosuppressive have already been confirmed $[10,11]$.

Through phytochemical studies of Maytenus species, pentacyclic triterpenes, sesquiterpenes, flavonoids, condensed tannins, alkaloids and other classes of organic compounds have been identified $[1,12]$. Pentacyclic triterpenes are more frequently isolated and have pharmacological properties such as anti-inflammatory action [13] antimicrobial [14] and hepatoprotective [15]. In the last years, there has been an increase in the interest for plants of the genus Maytenus, especially in Brazil, where there are 76 catalogued species, which are widely distributed throughout the Brazilian territory [1]. Maytenus ilicifolia, known as "espinheira-santa", is one of the few herbal medicines whose pharmacological effects have been approved by the Central de Medicamentos (CEME) of the Ministerio da Saúde of Brazil, which provides maximum safety in the use of medicines formulated with this species [16].

Maytenus acanthophylla, $M$. rigida and $M$. truncata are commonly used in the municipality of Jequié, Bahia, located in the Caatinga biome, which covers 844 thousand $\mathrm{km}^{2}$, representing $11 \%$ of the Brazilian territory, and is characterized by a semi-arid climate, of vegetation with little foliage and fully adapted to periods of intense drought [17]. In the Tupi-Guarani language, the name Caatinga (caa (forest) + tinga (white)) means "white forest" due to the predominant color of the vegetation that during the dry season, loses almost all the leaves to reduce perspiration and avoid the loss of stored water. On returning to the rainy season, the green leaves and flowers sprout again.

Maytenus acanthophylla, popularly known in the Jequié region as "pau-de-jararaca", is traditionally used in the treatment of gastritis, ulcers and other disorders of the digestive tract, such as antiseptic, anti-inflammatory, and in urogenital infections [12]. From M. acanthophylla have

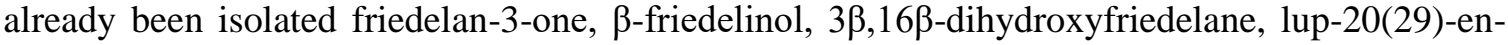

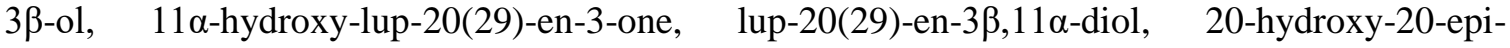
tingenone, pristimerine, 1,4-trans-polyisoprene, galactitol and other compounds [18, 19]. According to de Oliveira et al. (2012) [12], lupeol and 33-lup-20(29)-en-3-yl acetate, isolated in significant quantities from the aerial parts of $M$. acanthophylla, have anti-inflammatory and antimalarial properties.

Maytenus truncata, popularly known in the State of Bahia as "todo lado" and "todo jeito"is used as an infusion for the treatment of gastric ulcers and uterine diseases [1, 12]. Compounds such as $3 \alpha-$ and $3 \beta$-friedelinol, galactitol, glycosylated flavonoids (as example: quercetin-3-Otetraglycosylated, kaempferol-3-O-tetraglycosylated) were from $M$. rigida $[10,11]$. According to Salazar et al. (2000) [11], the hydromethanolic extract of M. truncata did not induce mutagenic effect through the formation of micronuclei, which demonstrates the low cytotoxicity of this extract.

Maytenus rigida, is popularly known as "bom homen", "cabelo-de-negro", "casca-grossa" and "pau-de-colher" and its roots are used to reduce pain in general and for the treatment of infections 
and inflammations [9]. This species is rich in bioactive metabolites, which have properties such as antimicrobial [20], antinoceptive [21], antioxidant [22], antiulcerogenic [23] and other pharmacological effects. From $M$. rigida were isolated friedelan-3-one, friedelan-3 $\beta$-ol, lupeol and hydroxyl derivatives, rigidenol, ursolic acid, 4'-O-methyl-(-)-epigallocatechin, wilforine, proanthocyanidins A and B [21, 22, 24-27].

Polar extracts obtained from $M$. acanthophylla, M. rigida and $M$. truncata are rich in polyphenols, especially flavonoids, whose chemical structures have the property of reacting with free radicals, mainly reactive oxygen species (ROS), generated by oxidative stresses including those produced by solar radiation [28]. Therefore, polyphenols are involved in processes of protection against harmful effects caused by excessive solar radiation [29].

In order to contribute to validate the use of $M$. acanthophylla, M. rigida and $M$. truncata in traditional medicine of the region of Jequié, Bahia the content of phenolic compounds in the polar extracts of these species were determined. The cytotoxicity of these extracts at different concentrations was evaluated by means of the median inhibitory concentration $\left(\mathrm{IC}_{50}\right)$ obtained through the bioassay using the microcrustacean Artemia salina. In addition, the sun protection factor was calculated for each polar extract.

\section{MATERIAL AND METHODS}

\subsection{Plant material}

Analyses leaves of $M$. acanthophylla were collected near the BR-116 highway. Leaves of $M$. truncata and leaves and roots of $M$. rigida were collected in the district of Cachoeirinha, located in the urban perimeter of the city of Jequié, Bahia. These regions are situated in the municipality of Jequié (135' $\left.15.38^{\prime \prime} \mathrm{S} ; 40^{\circ} 10^{\prime} 30.65^{\prime \prime} \mathrm{W}\right)$. After botanical identification, an exsiccata of each species was documented in the Herbarium of the State University of Southwest Bahia (UESB), being $M$. acanthophylla (HUESB-7813), M. truncata (HUESB-9311) and M. rigida (HUESB-7056). After collection, the leaves were dried at room temperature and ground in an industrial blender (Skywsem, model LSB-15). The roots of M. rigida were also dried at room temperature, fragmented and ground for further preparation of the extracts.

\subsection{Obtainment of extracts}

The ethanolic extract was prepared with leaves of $M$. acanthophylla $(500 \mathrm{~g})$ and $M$. truncata $(500 \mathrm{~g})$ and with the bark of the root of M. rigida $(500 \mathrm{~g})$ by means of exhaustive extraction with ethyl alcohol (95\%), in a Soxhlet apparatus, following the methodology described by [30]. In each extraction process, the ethanol was removed using a rotary evaporator at $60{ }^{\circ} \mathrm{C}$ and under reduced pressure. Ethanolic extract of $M$. acanthophylla (ETMA, $71.20 \mathrm{~g}, 14.24 \% \mathrm{~m} / \mathrm{m}$ ), M. truncata (ETMT, $78.50 \mathrm{~g}, 15.70 \% \mathrm{~m} / \mathrm{m}$ ) and $M$. rigida (ETMR, $145.15 \mathrm{~g}, 29.03 \%$ ) were obtained. The aqueous extracts of $M$. acanthophylla $(200 \mathrm{~g})$ and of $M$. truncata $(200 \mathrm{~g})$ was prepared by decoction of its leaves. For this purpose, the ground leaves were placed in a round-bottomed flask with filtered water and heated using a heating mantle for 15 minutes. Then, the obtained extract was first strained in cotton cloth to separate the raw residual material and the resulting solution was filtered under vacuum. Each aqueous extract was dehydrated by lyophilization, using a Terroni ${ }^{\circledR}$ Lyophilizer, LS Series, model 3000. The aqueous extract of $M$. acanthophylla (AQMA, $2.60 \mathrm{~g}, 1.30 \% \mathrm{~m} / \mathrm{m}$ ) and M. truncata (AQMT, $7.68 \mathrm{~g}, 3.84 \% \mathrm{~m} / \mathrm{m}$ ) was obtained.

\subsection{Total phenolic compounds}

The content of total phenolic compounds in the AQMA, AQMT, ETMA, ETMT and ETMR extracts were quantitatively evaluated using the Folin-Ciocalteau reagent by spectroscopy in the UV-Vis region. The analyses were performed using a BIOSPECTRO Spectrophotometer model SP-220, from the Jailson Bitencour Chromatography Laboratory, Department of Chemistry, UESB. Initially, the method was standardized by the following procedure: preparation of an aqueous solution of gallic acid $(500.0 \mu \mathrm{g} / \mathrm{mL})$ and then this stock solution was diluted to $250.0,150.0,100.0$ 
and $50.0 \mu \mathrm{g} / \mathrm{mL}$. In the cuvettes, $0.02 \mathrm{~mL}$ of each solution was added; $0.1 \mathrm{~mL}$ of Folin-Ciocalteau, $1.58 \mathrm{~mL}$ of distilled water and after $8 \mathrm{~min} 0.3 \mathrm{~mL}$ of $15 \% . \mathrm{Na}_{2} \mathrm{CO}_{3}$ was added. After 2 hours, a spectrophotometer reading was performed and the results were used to construct the calibration curve.

A stock solution containing $100.0 \mathrm{mg}$ of sample $/ 100 \mathrm{~mL}$ of methanol was prepared for each of the extracts. For the analysis, $7.5 \mathrm{~mL}$ of the methanol stock solution was diluted in a $50.0 \mathrm{~mL}$ volumetric flask. Aliquots of $100.0 \mu \mathrm{L}$ of this solution were transferred to a $10.0 \mathrm{~mL}$ volumetric flask and then $500.0 \mu \mathrm{L}$ of the Folin-Ciocalteau reagent and $6 \mathrm{~mL}$ of distilled water were added. The solution was homogenized by stirring for 1 minute. The solution was homogenized by agitation for 1 minute and soon after, $2 \mathrm{~mL}$ of $15 \% \mathrm{Na}_{2} \mathrm{CO}_{3}$ was added and the volume of the flask was completed with distilled water. After 2 hours, the absorbance of the solution at $750 \mathrm{~nm}$ was determined in a spectrophotometer, using methanol as a blank. The calibration curve was constructed relating the absorbance versus the concentration of gallic acid. The content of total phenolic compounds of each extract was quantified by means of the standard curve prepared with gallic acid, using the Student's t-test and the values expressed as gallic acid equivalents per gram of extract. All analyses were performed in triplicate and the data expressed as mean \pm mean standard error.

\subsection{Determination of total flavonoids}

The determination of the flavonoid content of AQMA, AQMT, ETMA, ETMT and ETMR extracts was performed by UV-Vis spectroscopy using the Folin-Ciocalteau reagent [31]. Rutin was used as a standard for the construction of the calibration curve. A methanolic solution of rutin $(500 \mathrm{ug} / \mathrm{mL})$ was prepared, and from this, dilutions were made to $250.0,150.0,100.0$ and 50.0 $\mu \mathrm{g} / \mathrm{mL}$, and the procedure was similar to that used in determining the total phenolic content.

\subsection{Photoprotective property}

The sun protection factor (SPF) of each extract was evaluated using a UV-Vis spectrophotometer, VARIAN model CARY 50, from the Laboratory of Analytical Chemistry II, UESB. Samples of the aqueous extracts AQMA, AQMT and the ethanolic extracts ETMA, ETMT and ETMR were diluted at $10.0 \mu \mathrm{g} / \mathrm{mL}$ in $50 \%$ ethyl alcohol. Then, the absorption of each solution was measured in the region of UV-B 290 to $320 \mathrm{~nm}$. The in vitro spectrophotometric method developed by Mansur et al. (1986) [32] was used. The estimate of the SPF was according to the formula:

$$
\operatorname{SPF}_{\text {Spectrophotometri }} \mathrm{c}=\mathrm{CF} \times \sum_{290}^{320} \mathrm{EE}(\lambda) \times \mathrm{I}(\lambda) \times \operatorname{ABS}(\lambda)
$$

being, EE (1) = erythemal effect spectrum; I $(1)=$ solar intensity spectrum; Abs $(1)=$ absorbance of sunscreen product (Extract data); $\mathrm{CF}=$ correction factor $(=10)$. For each wavelength the following EE x 1 values were used: $0.0150(290 \mathrm{~nm}), 0.0817(295 \mathrm{~nm}), 0.2874(300 \mathrm{~nm}), 0.3278(305 \mathrm{~nm})$, $0.1864(310 \mathrm{~nm}), 0.0839(315 \mathrm{~nm})$ and $0.0180(320 \mathrm{~nm})$. These values of EE x I are constants previously normalized by Sayre et al. (1979) [33] and referenced by Mansur et al. (1986) [32].

\subsection{Toxicity of extracts}

To determine toxicity of the studied extracts, the assay with brine shrimp Artemia salina was carried out: $25 \mathrm{mg}$ of class $\mathrm{C}$ eggs, from the local market, were incubated in a hatching chamber with artificial salt water, at $28 \pm 2{ }^{\circ} \mathrm{C}$, with constant lighting. Artificial salt water consisted of $23 \mathrm{~g}$ $\mathrm{NaCl}, 11 \mathrm{~g} \mathrm{MgCl}_{2} \cdot 6 \mathrm{H}_{2} \mathrm{O}, 4 \mathrm{~g} \mathrm{Na}_{2} \mathrm{SO}_{4}, 1.3 \mathrm{~g} \mathrm{CaCl}_{2} \cdot 2 \mathrm{H}_{2} \mathrm{O}, 0.7 \mathrm{~g} \mathrm{KCl}$ in $1 \mathrm{~L}$ distilled water. The $\mathrm{pH}$ was adjusted to 9.0 using $\mathrm{Na}_{2} \mathrm{CO}_{3}$ to avoid risk of death to the Artemia larvae by decrease of $\mathrm{pH}$ during incubation $[34,35]$. After $24 \mathrm{~h}, 15 \mathrm{~mL}$ of yeast solution $0.06 \%$ was added to the chamber for every liter of salt water in order to feed the larvae; $48 \mathrm{~h}$ after the eggs incubation, the larvae 
were extracted and counted using a Pasteur pipette. For each Maytenus extract, six concentrations were tested in order to determine dose-response relationship. For each Maytenus extract - AQMA, AQMT, ETMA, ETMT and ETMR - a stock solution of $2000.0 \mu \mathrm{g} / \mathrm{mL}$ was prepared. From this solution were obtained, in test tubes, dilutions with artificial salt water solution of 1.0, 10.0, 100.0, $250.0,500.0$ and $1000.0 \mu \mathrm{g} / \mathrm{ml}$. The salt water solution was applied in control assay performed without Maytenus extract. Every test tube with sample contained 10 larvae of brine shrimp, including the control group, and was filled to $5 \mathrm{ml}$ total volume with artificial salt water. After 24 $\mathrm{h}$ at $28 \pm 2{ }^{\circ} \mathrm{C}$, live larvae were counted. The results were tabulated and the median lethal concentration value $\left(\mathrm{LC}_{50}\right)$ was determined using the Trapversion 3.0 software. All experiments were performed in triplicate.

\subsection{Statistical analysis}

The Student's t-test was performed for group analysis of total phenolic compounds and total flavonoides.

\section{RESULTS AND DISCUSSION}

The aqueous extracts of the leaves, M. acanthophylla and M. truncata, were prepared with the objective of obtaining a substance with chemical composition similar to that of the teas that are traditionally prepared, that is, by decoction. The preparation of extracts from the roots of M. rigida was done by decoction because this is a part of the plant also frequently used by the population of Jequié, Bahia.

Polar extracts of these plants contain different phenolic compounds. The study of phenolic compounds and flavonoids is important because of their pharmacological properties. Because of this and since they are medicinal plants, a comparison of the total phenolic compounds in polar extracts of $M$. acanthophylla, $M$. rigida and $M$. truncata was evaluated. The total phenolic content in AQMA, AQMT, ETMA, ETMT and ETMR extracts are described in Table 1. The results were expressed as gallic acid equivalent for the dosage of phenolic and rutin equivalent for flavonoids, from the respective calibration curves established for these standards. The use of water and ethanol in the preparation of $M$. acanthophylla, $M$. rigida and $M$. truncata extracts was made to maximize the extraction of phenolic components, due to their greater affinity for polar solvents [36, 37]. The Student's t-test showed no significant differences between the mean total phenolic and total flavonoid levels. However, a higher content of these compounds was found in the ethanolic extract of $M$. rigida roots (ETMR), followed by the aqueous extract of M. acanthophylla (AQMA) (Table 1). Phenolic compounds act as antioxidants and are therefore essential for delaying aging, disease prevention and human health. Thus, the results obtained in this study corroborate the importance of the popular use of these species of Maytenus.

Besides the biochemical aspects of each species, Gobbo-Neto and Lopes (2007) [38] reaffirm that intrinsic or extrinsic environmental factors also alter the biosynthesis of certain metabolites in vegetables, including flavonoids, which consequently interferes in the concentration of these compounds.

Table 1: Content of phenolic compounds and total flavonoids in the aqueous extract of Maytenus acanthophylla (AQMA) and M. truncata (AQMT) and the ethanolic extract of M. acanthophylla (ETMA), $M$. truncata (ETMT) and M. rigida (ETMR), using as reference the calibration curve of absorbance versus concentration of galic acid.

\begin{tabular}{lccccc}
\hline \multirow{2}{*}{ Sample } & Total phenolics & Total flavonoids & \multicolumn{3}{c}{ T-test } \\
\cline { 4 - 6 } & $(\boldsymbol{\mu g} / \mathbf{m L})$ & $(\boldsymbol{\mu g} / \mathbf{m L})$ & tcalc & tcrit & $(\mathbf{P})$ \\
\hline AQMA & $50 \pm 3.52$ & $53 \pm 4.92$ & -0.42 & 2.13 & 0.32 \\
AQMT & $33 \pm 3.52$ & $29 \pm 4.92$ & 0.20 & 2.13 & 0.42 \\
ETMA & $31 \pm 2.11$ & $26 \pm 2.92$ & 0.54 & 2.13 & 0.31 \\
ETMT & $32 \pm 1.15$ & $28 \pm 1.61$ & 3.25 & 3.74 & 0.01 \\
ETMR & $59 \pm 1.72$ & $67 \pm 2.41$ & -4.23 & 2.13 & 0.01 \\
\hline
\end{tabular}


tcalc $=$ Calculated $t$-value $;$ tcrit $=$ critical $t$-value $($ Student $) ; P=$ tcalc $\leq$ tcrit probability $($ One tailed test $)$.

Flavonoids present an intense absorption band in the ultraviolet region through two characteristic bands: band I, in the range of 300 to $550 \mathrm{~nm}$, resulting from the maximum absorption of ring B and band II, in the range of 240 to $285 \mathrm{~nm}$, resulting from the absorption of ring A [39]. These absorption bands are correlated to the presence of flavonoids containing free and/or glycosylated aglycosides [39].

Spectra in the UV-Vis region of AQMA, AQMT, ETMA, ETMT and ETMR (Figure 1) showed absorption bands in the region of 255 to $290 \mathrm{~nm}$ and 330 to $370 \mathrm{~nm}$, associated with the presence of flavonoids, which represents a potential antioxidant property of these extracts.

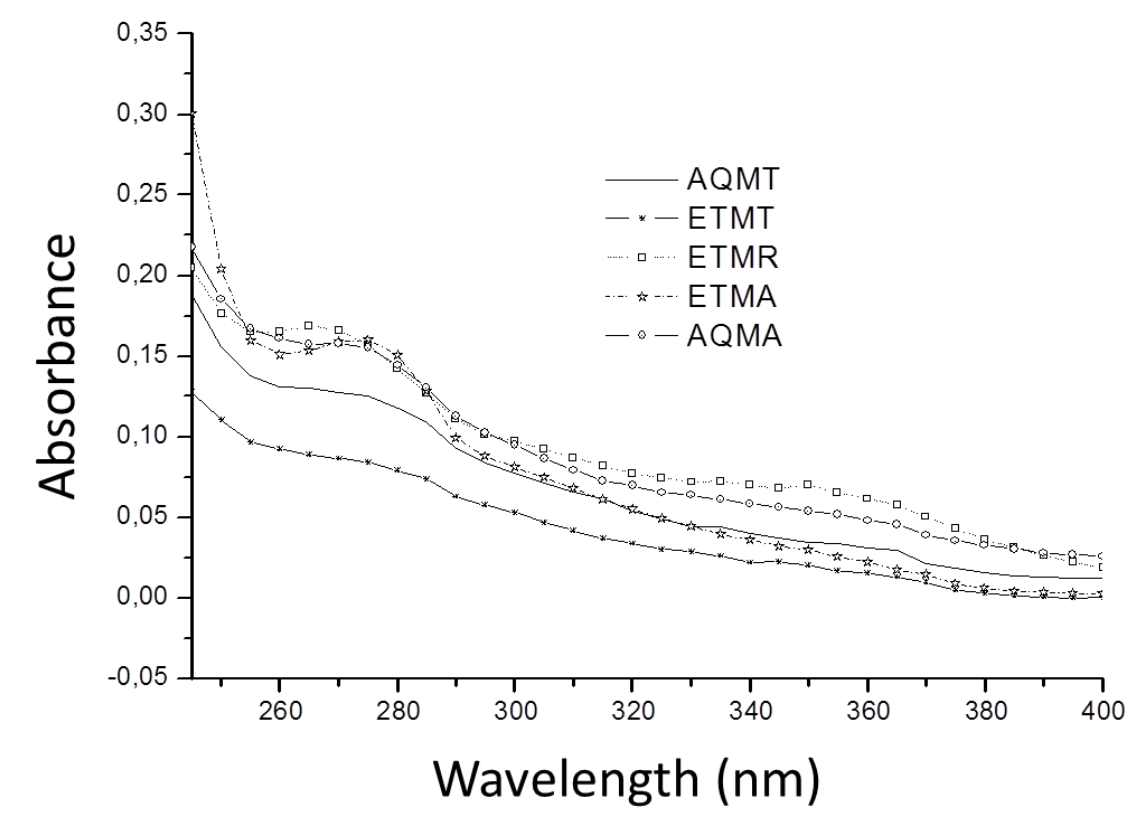

Figure 1: Absorption spectra in the UV-Vis region of the aqueous extracts of Maytenus acanthophylla (AQMA) and M. truncata (AQMT) and ethanolic extracts of M. acanthophylla (ETMA), M. truncata (ETMT) and M. rigida (ETMR).

The photoprotective property of AQMA, AQMT, ETMA, ETMT and ETMR extracts was evaluated by absorption in the UV-B region ( 295 to $320 \mathrm{~nm}$ ). The intensity of absorption of the extracts in the region between 260 and $320 \mathrm{~nm}$ (Figure 1) indicated the presence of compounds containing chromophore groups that are associated with protection from the effects of solar radiation. The sun protection factor calculated for the aqueous extracts of the three Maytenus species studied is presented in Table 2 .

Table 2: Sun protection factor (SPF) calculated for aqueous extracts of Maytenus acanthophylla (AQMA) and M. truncata (AQMT) and ethanolic extracts of M. acanthophylla (ETMA), M. truncata (ETMT) and M. rigida (ETMR).

\begin{tabular}{cc}
\hline Maytenus extract & SPF $_{\text {Calculated }}$ \\
\hline AQMA & 10.6 \\
AQMT & 11.4 \\
ETMA & 11.3 \\
ETMT & 13.3 \\
ETMR & 10.3 \\
\hline
\end{tabular}


According to the wavelengths UV light is classified as UV-A (320 to $400 \mathrm{~nm}$ ), UV-B (290 to $320 \mathrm{~nm}$ ) and UV-C light (100 to $280 \mathrm{~nm}$ ). UV-C radiation is completely absorbed by stratospheric ozone, whereas UV-A and UV-B radiation reach the earth's surface and have been strongly implicated in the development of skin cancers. Therefore, it is important to protect skin against the harmful effects of UV-A and UV-B light [40, 41].

The effects of UV-A and UV-B radiation on normal-appearing skin, which are mostly adverse, may be acute or chronic. The acute effects include erythema (sunburn), pigmentation (tanning) caused by UV-B and reduction of blood pressure by UV-A. Chronic effects include photooncogenesis and photoaging [41]. All effects are underpinned by molecular or cellular effects such as DNA damage, the generation of reactive oxygen species (singlet oxygen, superoxide, peroxyl radicals, hydroxyl radicals and peroxynitrite), melanogenesis, apoptosis and expression of many genes and related proteins [41]. The only widely established benefit of sun radiation in the skin is the photosynthesis of vitamin D that is initiated by the UV-B-induced conversion of epidermal 7-dehydrocholesterol into pre-vitamin D3 [41].

Due to UV-B radiation causes sunburn, the SPF of a sunscreen measures protection from UV-B radiation only. Sunscreens are agents that temporarily block UV radiation absorption by the skin. Filters or sunscreen protectors with values between 8 and 16 confer from 84 to $97 \%$ protection against solar radiation. No protector offers $100 \%$ protection. The sun filter with protection factor 15 blocks the major part (nearly 94\%) of the UV-B rays. The use of solar filters $\geq 15$ slightly increases the UV-B blocking. However, the longer the sunscreen will continue to absorb UV-B rays, the higher the SPF value, thus decreasing the frequency of application [42]. Thus, the SPF values found for the extracts of Maytenus species studied are promising. It is interesting to note that the raw polar extracts were studied, which are composed of complex mixtures, in which the active components are in low concentration. Probably, the photoprotective property, associated with the intensity of absorption, would be more significant if the active components were in greater concentration or if the active constituents were analyzed pure. According to Munhoz et al. (2012) [29], phenolic compounds have become the target of investigation as potential sun filters, due to these compounds having a chemical structure similar to that of sun filters used in cosmetology, whose structure in general contains a benzopyran or chroman nucleus coupled to an aromatic ring. The results found in this work open perspectives for the investigation of this photoprotection property using other concentrations of the extracts and also using fractions or pure isolated constituents.

Brine shrimp lethality bioassay is a simple, high throughput cytotoxicity test for bioactive chemicals, including plant extracts [43]. For this reason, the cytotoxicity of polar extracts of the Maytenus species studied was evaluated using the A. salina model. Mortality of A. salina due to exposure to polar extracts obtained from the three Maytenus species is listed in Table 3.

A dose-response relationship was observed for all extracts, which made it possible to use the mortality values to determine the median lethal concentration $\left(\mathrm{LC}_{50}\right)$ of each extract. According to Meyer et al. (1982) [43], $\mathrm{LC}_{50}$ values of $\leq 1000 \mu \mathrm{g} / \mathrm{mL}$ determined using the A. salina test classify the plant extract as cytotoxic, and the lower the value found, the greater its toxicity. Values ranging from 500 to $1000 \mu \mathrm{g} / \mathrm{mL}$ are considered mild cytotoxicity, those between 100 and $500 \mu \mathrm{g} / \mathrm{mL}$ as moderate cytotoxicity and those $<100 \mu \mathrm{g} / \mathrm{mL}$ as high cytotoxicity [44, 45]. The $\mathrm{LC}_{50}$ values determined for the polar extracts of the four Maytenus species were less than $1000 \mu \mathrm{g} / \mathrm{mL}$. The aqueous extract of $M$. truncata (AQMT) was the one with the highest value of $\mathrm{LC}_{50}$ and was considered to have mild cytotoxicity. On the other hand, the ethanolic extract of M. rigida (ETMR) was considered of moderate cytotoxicity $\left(\mathrm{LC}_{50}=283 \pm 7.73\right)$, followed by the ethanolic extract of M. acanthophylla (ETMA) $\left(\mathrm{LC}_{50}=372 \pm 8.16\right)$ (Table 3).

The evaluation of cytotoxic activity is useful for obtaining the biological profile of natural products. Generally, substances with cytotoxic properties have been correlated to potential biological activities of interest, such as antitumor, antifungal, antimicrobial and other. Thus, a natural substance with high cytotoxicity has been considered interesting for the conduct of pharmacological studies.

The low relative toxicity of the aqueous extract of $M$. acanthophylla (AQMA) and M. truncata (AQMT) and the ethanolic extract of $M$. truncata (ETMT) whose $\mathrm{LC}_{50}$ values varied between 527 \pm 6.71 and $943 \pm 4.57 \mu \mathrm{g} / \mathrm{mL}$ are in agreement with the use of these plants in popular medicine. 
Table 3: Artemia salina mortality rate and median lethal concentration $\left(L_{50}\right)$ determined for the aqueous extracts of Maytenus acanthophylla (AQMA) and of M. truncata (AQMT) and of the ethanolic extracts of M. acanthophylla (ETMA), M. truncata (ETMT) and M. rigida (ETMR).

\begin{tabular}{|c|c|c|c|c|c|}
\hline \multicolumn{2}{|c|}{$\begin{array}{c}\text { Sample } \\
(\mu \mathrm{g} / \mathrm{mL})\end{array}$} & $\begin{array}{l}\text { Mortality } \\
\text { rate } *\end{array}$ & $\begin{array}{c}\mathbf{L C}_{50} \\
(\mu \mathrm{g} / \mathrm{mL})\end{array}$ & $\begin{array}{c}\text { Max }- \text { Min** } \\
\text { concentration } \\
(\mu \mathrm{g} / \mathrm{mL})\end{array}$ & $\begin{array}{l}\text { Slope of the } \\
\text { curve }\end{array}$ \\
\hline & 1 & 0.7 & & & \\
\hline AQMT & $\begin{array}{c}10 \\
100 \\
250 \\
500 \\
1000\end{array}$ & $\begin{array}{l}1.0 \\
2.0 \\
2.7 \\
4.4 \\
5.4\end{array}$ & $943 \pm 4.57$ & $674.99-1319.47$ & 0.49597 \\
\hline ETMT & $\begin{array}{c}1 \\
10 \\
100 \\
250 \\
500 \\
1000\end{array}$ & $\begin{array}{l}0.4 \\
1.7 \\
2.0 \\
2.4 \\
4.7 \\
9.7\end{array}$ & $527 \pm 6.71$ & $322.40-862.98$ & 1.5446 \\
\hline ETMR & $\begin{array}{c}1 \\
10 \\
100 \\
250 \\
500 \\
1000\end{array}$ & $\begin{array}{l}0.7 \\
1.4 \\
2.4 \\
5.7 \\
6.4 \\
9.0\end{array}$ & $283 \pm 7.73$ & $161.10-500.50$ & 0.77641 \\
\hline ETMA & $\begin{array}{c}1 \\
10 \\
100 \\
250 \\
500 \\
1000\end{array}$ & $\begin{array}{l}1.4 \\
2.4 \\
3.4 \\
4.7 \\
6.4 \\
9.4\end{array}$ & $372 \pm 8.16$ & $204.69-677.17$ & 0.93865 \\
\hline AQMA & $\begin{array}{c}1 \\
10 \\
100 \\
250 \\
500 \\
1000\end{array}$ & $\begin{array}{l}1.0 \\
3.0 \\
3.7 \\
3.4 \\
4.7 \\
9.0\end{array}$ & $608 \pm 0.16$ & $188.71-1959.75$ & 0.92999 \\
\hline
\end{tabular}

* Mortality observed in groups of 10 A. salina tested. ** Confidence limit 95\%.

\section{CONCLUSION}

Higher content of phenolic compounds and total flavonoids was found in the ethanolic extract of the roots of $M$. rigida, followed by the aqueous extract of $M$. acanthophylla. In relation to the photoprotective property, the SPF value found for the extracts of the three Maytenus species are promising, and can be related to the respective antioxidant properties. Through the A. salina assay, the aqueous extract of $M$. truncata was considered light toxicity $\left(\mathrm{LC}_{50}=943 \pm 4.57\right)$ and the ethanolic extract of $M$. rigida, moderate toxicity $\left(\mathrm{LC}_{50}=283 \pm 7.73\right)$, followed by the ethanolic extract of M. acanthophylla $\left(\mathrm{LC}_{50}=372 \pm 8.16\right)$. The results found in this work reinforce the rational use of these plants, but under the guidance of a physician or pharmacist, so that their use does not cause undesirable and/or toxic effects. This study contributes to the knowledge of Celastraceae species native to the State of Bahia, Brazil. 


\section{ACKNOWLEDGMENTS}

The authors thank to Fundação de Amparo à Pesquisa do Estado da Bahia (FAPESB) and to Universidade Estadual do Sudoeste da Bahia for providing financial support throughout the development of this work.

\section{REFERENCES}

1. Niero R, Andrade SF, Fillho VC. A review of the ethnopharmacology, phytochemistry and pharmacology of plants of the Maytenus genus. Curr Pharm Des. 2011;7(0):11-22, doi: 10.2174/138161211796391029

2. Ferreira HL, Neves LLM, Binsfeld PC. Inserção dos fitoterápicos no complexo produtivo e inovação em saúde. In: BRASIL. Ministério da Saúde. Organização Pan-Americana da Saúde. Inovação em temas estratégicos de saúde pública. Brasília, DF: Ministério da Saúde, 2011; (Série B. Textos Básicos de Saúde, v. 1): 103-120.

3. OPAS. Organização Pan-Americana da Saúde. Declaração de Alma-Ata. In: Conferência Internacional Sobre Cuidados Primários de Saúde, 6-12 set 1978, Alma-Ata. [cited 2019 Set 05]. Available from: http://cmdss2011.org/site/wp-content/uploads/2011/07/Declara\%C3\%A7\%C3\%A3o-Alma-Ata.pdf.

4. OMS. Organização Mundial da Saúde. Estratégia da OMS Sobre Medicina Tradicional. 2002-2005. Genebra: OMS; 2002. [cited 2019 Set 05]. Available from: https://www.paho.org/bra/index.php?option=com_docman\&view=download\&alias=796-estrategiaoms-sobre-medicina-tradicional-2002-2005-6\&category_slug=vigilancia-sanitaria-959\&Itemid=965.

5. França ISX, de Souza JA, Baptista RS, Britto VRS. Medicina popular: benefícios e malefícios das plantas medicinais. Rev Bras Enferm. 2008;61(2):201-2008, doi: 10.1590/S0034-71672008000200009

6. Silva FC, Duarte LP, Vieira Filho AS. Celastráceas: Fontes de Triterpenos Pentacíclicos com Potencial Atividade Biológica. Rev Virtual Quim. 2014;5(6):1205-1220, doi: 10.5935/1984-6835.20140079

7. Bukhari SN, Jantan I, Seyed MA. Effects of Plants and Isolates of Celastraceae Family on Cancer Pathways. Anticancer Agents Med Chem. 2015;15(6):681-93, doi: 10.2174/1871520615666150318101149

8. Simmons MP, Cappa JJ, Archer RH, Ford AJ, Eichstedta D, Clevinger CC. Phylogeny of the Celastreae (Celastraceae) and the relationships of Catha edulis (qat) inferred from morphological characters and nuclear and plastid genes. Mol Phylogenet Evol. 2008;48(2):745-757, doi:10.1016/j.ympev.2008.04.039

9. Spivey AC, Weston M, Woodhead S. Celastraceae sesquiterpenoids: biological activity and synthesis. Chem Soc Rev. 2002;31(1):43-59, doi: 10.1039/b000678p

10. Fonseca APND, Silva GDF, Carvalho JJ, Salazar GDCM, Duarte LP, Silva RP, Jorge RM, Tagliati CA, Zani CL, Alves TMA, Peres V, Vieira Filho SA. Estudo fitoquímico do decocto das folhas de Maytenus truncata Reissek e avaliação das atividades antinociceptiva, antiedematogênica e antiulcerogênica de extratos do decocto. Quím Nova. 2007;30:842-7, doi: 10.1590/S0100-40422007000400016

11. Salazar MM, Silva GDF, Duarte LP, Vieira Filho SA, Lula IS. Two epimeric friedelane triterpenes isolated from Maytenus truncata Reiss: ${ }^{1} \mathrm{H}$ and ${ }^{13} \mathrm{C}$ chemical shift assignments. Magn Reson Chem. 2000;38(11):977-980, doi:10.1002/1097-458X(200011)38:11<977::AID-MRC757>3.0.CO;2-9

12. de Oliveira DM. Estudo químico, farmacológico e aplicação de métodos computacionais na elucidação estrutural de constituintes químicos de folhas de Maytenus acanthophylla Reissek (Celastraceae) [tese]. Minas Gerais: Doutorado em ciências químicas, Universidade Federal de Minas Geais; 2012. Available at: http://hdl.handle.net/1843/SFSA-AA3VNE (Accessed at November, 10, 2019).

13. Reyes CP, Núñez MJ, Jiménez IA, Busserolles J, Alcaraz MJ, Bazzocchi L. Activity of lupane triterpenoids from Maytenus species as inhibitors of nitric oxide and prostaglandin E2. Bioorg Med Chem. 2006;14:1573-1579, doi: 10.1016/j.bmc.2005.10.063

14. Chung PY, Navaratnam P, Chung LY. Synergistic antimicrobial activity between pentacyclic triterpenoids and antibiotics against Staphylococcus aureus strains. An Clin Microbiol Antimicrob. 2011;10:25-30, doi: 10.1186/1476-0711-10-25

15. Sunitha S, Nagara JM, Varalakshmi P. Hepatoptotective effect of lupeol and lupeol linoleate on tissue antioxidant defense system in cadmium-induced hepatotoxicity in rats. Fitoterapia. 2001;72:516-523, doi: 10.1016/s0367-326x(01)00259-3

16. Anvisa. Agência Nacional de Vigilância Sanitária. Formulário de Fitoterápicos da Farmacopéia Brasileira. Brasília: Anvisa, 2011: 1-126. [cited 2019 Set 05]. Available from: http://portal.anvisa.gov.br/formulario-fitoterapico

17. MMA. Ministério do Meio Ambiente, Brasil. Caatinga. [cited 2019 Set 05]. Available from: http://www.mma.gov.br/biomas/caatinga 
18. de Oliveira DM, Silva GDF, Duarte LP, Vieira Filho SA. Chemical constituents isolated from roots of Maytenus acanthophylla Reissek (Celastraceae). Biochem Syst Ecol. 2006;34(8):661-665, doi: 10.1016/j.bse.2006.03.002

19. Filho WDA, Araújo LMP, Oliveira DM, Mauricio CRM. Annexation of biologically active compounds extracted from plants in the lipid layers of micro bubbles for the localized treatment of diseases. Int $\mathbf{J}$ Current Res. 2018;10(8):72208-72211, doi: 10.24941/ijcr.31979.08.2018

20. Santos VL, Souza MFV, Batista LM, Silva BA, Lima MS, Souza AMF, Barbosa FCI, Catão RMR. Avaliação da atividade antimicrobiana de Maytenus rigida Mart. (Celastraceae). Rev Bras Pl Med. 2011;13(1):68-72, doi: 10.1590/S1516-05722011000100010

21. Dias KS, Marques MS, Menezes IAC, Santos TC, Silva ABL, Estevam CS, Sant'Ana AEG, Pizza C, Antoniolli AR, Marcal RM. Antinociceptive activity of Maytenus rigida stem bark. Fitoterapia. 2007;78(7-8):460-464, doi: 10.1016/j.fitote.2007.02.017

22. Estevam CS, Cavalcanti AM, Cambui EVF, Araujo Neto V, Leopoldo PTG, Fernandes, RPM, de Araujo BS, Porfirio Z, Sant'Ana AEG. Phytochemistry and microbiological assay of the bark extracts of Maytenus rigida Mart. (Celastraceae). Rev Bras Farmacogn. 2009;19(1B):299-303, doi: 10.1590/S0102695X2009000200020

23. Santos VL, Costa VBM, Agra MF, Silva BA, Batista LM. Pharmacological studies of ethanolic extracts of Maytenus rigida Mart (Celastraceae) in animal models. Rev Bras Farmacogn. 2007;17:336-342, doi:10.1590/S0102-695X2007000300006

24. Delle Monache F, Pomponi M, Marini-Bettolo GB, D'Albuquerque IL, Goncalves de Lima O. A methylated catechin and proanthocyanidins from the Celastraceae. Phytochemistry. 1976;15(4):573-4.

25. Gonzalez AG, Fraga BM, Gonzalez P, Marta M, Delle Monache F, Marini-Bettolo GB, De Mello JF, Goncalves O. A revised structure for the triterpene rigidenol. Phytochemistry. 1982:21(2):470-1, doi: 10.1016/S0031-9422(00)95296-8

26. Oliveira AF; Salatino A. Major constituents of the foliar epicuticular waxes of species from the Caatinga and Cerrado. J Biosci. 2000;55(9-10):688-92, doi: 10.1515/znc-2000-9-1003

27. Martins MV, Estevam CS, Santos ALLM, Dias AS, Cupertino-da-Silva YK, Araujo-Junior JX, Miranda ALP, Barreiro EJ, Pizza C, Piacente S, Montoro P, Quintans-Júnior LJ, Araujo BS, Alexandre-Moreira MS, Sant'Ana AEG. Antinociceptive effects of an extract, fraction and an isolated compound of the stem bark of Maytenus rigida. Rev Bras Farmacogn. 2012;22(3):598-60 3, doi:10.1590/S0102695X2012005000007

28. Barreiros ALBS, David JM, David JP. Estresse oxidativo: relação entre geração de espécies reativas e defesa do organismo. Quím Nova. 2006;29(1):113-123, doi: 10.1590/S0100-40422006000100021

29. Munhoz VM, Lonni AASG, de Mello JCP, Lopes CG. Avaliação do fator de proteção solar em fotoprotetores acrescidos com extratos da flora brasileira ricos em substâncias fenólicas. Rev Ciênc Farm Básica Apl. 2012;33(2):225-232.

30. Mendes SS, Andrade JÁ, Xavier MA, Junior JAS, Pantaleão SM, Estevam CS, et al. Genotoxicity test of Maytenus rigida and Aristolochia birostrisin the radicular meristem of the onion, Allium cepa. Rev Bras Farmacog. 2012 Jan/Feb;22(1):76-81, doi: 10.1590/S0102-695X2011005000180

31. Wagner, H., Bladt, S. Plant Drug Analysis: A Thin Layer Chromatography Atlas. Berlin, New York: Springer, 1996, $384 \mathrm{p}$.

32. Mansur JS, Breder MNR, Mansur MCA, Azulay RD. Determinação do fator de proteção solar por espectrofotometria. An Bras Dermatol. 1986;61(3):121-124.

33. Sayre RM, Agin, PP, LeVee GJ, Marlow E. A comparison of in vivo and in vitro testing of sunscreening formulas. Photochem photobiol. 1979;29:559.566, doi: 10.1111/j.1751-1097.1979.tb07090.x

34. Lewan L, Andersson M, Morales-Gomez P. The use of Artemia salina in toxicity testing. Altern Lab Anim. 1992;20:297-301.

35. Parra LA, Yhebra SR, Sardiñas GI, Buela IL. Comparative study of the assay of Artemia salina L. and the estimate of the medium lethal dose ( $\mathrm{LD}_{50}$ value) in mice, to determine oral acute toxicity of plant extracts. Phytomedicine. 2001;8(5):395-400, doi: 10.1078/0944-7113-00044

36. Spagolla LC, Santos MM, Passos LML, Aguiar CL. Extração alcoólica de fenólicos e flavonóides totais de mirtilo "Rabbiteye" (Vaccinium ashei) e sua atividade antioxidante. Rev Ci Farm Básica Apl. 2009;30(2):187-191.

37. Tiwari P, Kumar B, Kaur M, Kaur G, Kaur H. Phytochemical screening and Extraction: a review. Int Pharm Sci. 2011;1(1)98-106.

38. Gobbo-Neto L, Lopes NP. Plantas medicinais: fatores de influência no conteúdo de metabólitos secundários. Química Nova. 2007;30(2)374-371, doi: 10.1590/S0100-40422007000200026

39. Huber LS, Rodriguez-Amaya DB. Flavonóis e flavonas: fontes brasileiras e fatores que influenciam a composição em alimentos. Alim Nutr. 2008;19(1):97-108. 
40. Mulliken JS, Russak JE, Rigel DS. The effect of suscreen on melanoma risk. Dermatol Clin. 2012;30:369376, doi: 10.1016/j.det.2012.04.002.

41. Young AR, Claveau J, Rossi AB. Ultraviolet radiation and the skin: Photobiology and sunscreen photoprotection. J Am Acad Dermatol. 2017;78(3):S100-S108, doi: 10.1016/j.jaad.2016.09.038

42. Flor J, Davolos MR, Correa MC. Protetores solares. Quim Nova. 2007;30(1):153-158, doi: 10.1590/S0100-40422007000100027

43. Meyer BN, Ferrigni NR, Putnan JE, Jacobsen LB, Nichols DE, McLaughlin J. Brine shrimp: A convenient general bioassay for active plant constituents. J Med Plant Res. 1982;45(1):31-34, doi: 10.1055/s-2007971236

44. Nguta JM, Mbaria JM, Gakuya DW, Gathumbi PK, Kabasa JD, Kiama SG. Evaluation of acute toxicity of crude plant extracts from Kenyan biodiversity using brine shrimp, Artemia salina L. (Artemiidae). Open Conf Proc J. 2012;3:30-34, doi: 10.2174/2210289201203010030

45. Karchesy YM, Kelsey RG, Constantine G; Karchesy JJ. Biological screening of selected Pacific Northwest forest plants using the brine shrimp (Artemia salina) toxicity bioassay. Springerplus. 2016;5:510. doi: 10.1186/s40064-016-2145-1 